\title{
Bending and energy absorption performance of novel openwork wooden panels
}

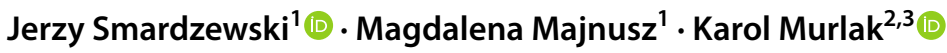

Received: 8 June 2021 / Accepted: 28 January 2022 / Published online: 10 February 2022

(c) The Author(s) 2022

\begin{abstract}
In many scientific studies, beams reinforced with synthetic fiber ribbons are modeled, wood composites and materials are designed, and structures made with hollow core boards are developed. However, no research was conducted on increasing the width of the flat wooden panels by modeling an openwork structure and obtaining them from solid panels of smaller width. The research aimed to determine the impact of wood species and inclination angle of the side walls on the stiffness, strength, and ability to absorb the energy of the new openwork panel made of curvilinear wooden slats. Three-point bending tests were performed numerically and verified experimentally. It has been shown that the stiffness of the openwork panels was lower compared to solid panels. No cracks in the glue line were observed. Walnut openwork panels demonstrated the best energy absorption capacity. Therefore, it is recommended that the openwork panels be made out of walnut and beech wood, rather than ash and oak. It is also more advantageous for the panel's construction to use the $11^{\circ}$ inclination angle of the side walls.
\end{abstract}

\section{Introduction}

For centuries, wood has been the primary material for the production of furniture. It is a renewable material, but its rational use is still a challenge for designers and constructors. In the interest of the best use of wood, its protection, modification, multilayer gluing, and optimization of crosssections ensuring sufficient stiffness and strength of the structure are carried out. In the literature, we can find many original methods to improve the mechanical quality of wood. Today many ways to attain a lighter wooden structure are on offer, some of them following partially the industrial application and only very few of them following the natural solution. The first one uses light-weight wood species limited by the availability, strengths, processability, etc. The second one is the sandwich structure made from rigid facings and cores made from soft structures. The third way to produce a

Jerzy Smardzewski

jsmardzewski@up.poznan.pl

1 Department of Furniture Design, Faculty of Forestry and Wood Technology, Poznan University of Life Sciences, Wojska Polskiego 28, 60-637 Poznan, Poland

2 Pratt Institute, 200 Willoughby Avenue, Brooklyn, NY 11205, USA

3 SWPS University of Social Sciences and Humanities, Chodakowska 19/31, 03-815 Warsaw, Poland light structure is to reduce the core weight drastically, using predesigned cavities or skeletons with unique shapes and connections to the faces (Berger et al. 2016).

Gaff et al. (2015a, b, 2016, 2017) and Gaff and Babiak (2018) examined several factors for wood bendability and demonstrated that wood species, densification, and material thickness are significant factors for bendability. With increasing thickness of the beams, the bendability coefficients decrease, and the proportionality limit increases. Yaddanapudi et al. (2017) replaced lignin with the polymer in wood cells, resulting in transparent wood material. It has higher tensile strength and hardness when compared to the delignified wood. Borri et al. (2005) showed that fiber-reinforced plastic materials' external bonding increases flexural stiffness and capacity of wood. The results showed increased flexural capacity up to $60.3 \%$ compared to un-reinforced beams when three carbon fiber reinforced plastic layers (CFRP) were used. The method of applying the composite reinforcement also produced a maximum stiffness increase of $27.7 \%$. The application by De Jesus et al. (2012) of CFRP laminates resulted in higher stiffness values compared to the ones obtained with non-reinforced beams. The interfacial shear and peeling stresses play a central role in assessing reinforced beams, and higher stiffness values were achieved by reducing interfacial stress peaks with the increase in reinforcement length. 
CFRP materials effectively reduce wood weakening and increase the bending stiffness of glued beams by $36 \%$ and about $20 \%$ for solid wood beams (Wdowiak-Postulak and Brol 2020). A comparison study between glass fiber reinforced polymer-wood sandwich beams (GFRP-W) with flatwise and sidewise directions showed that composite sandwich beams in flatwise bending tests failed under a lower load but yielded a more significant deflection than those in sidewise bending tests (Qi et al. 2017). According to Yang et al. (2013), a new fiber reinforced plastic and hybrid fiber-reinforced polymer (HFRP) can be effectively used to enhance the strengthened wood beams' ductility under the increased bending moment capacity. HFRP is also a cheaper material than carbon fiber or glass fiber. Borri et al. (2013) also tested reinforcing the solid wood with composite materials based on natural fibers in the form of fabrics (made from hemp, flax, basalt, and bamboo fibers). The use of natural fibers increases the load-carrying capacity, increasing the material's stiffness and ductility. The advantages of this solution are low production costs, low pollution emissions, and energy consumption for production.

Other methods of improving the mechanical quality of wood are producing sandwich composites using wood and wood materials or plastics. According to Anshari et al. (2012), reinforcing beams with densified wood (DW) is economical and environmentally friendly. Only a tiny amount of densified wood is required, and no bonding between the DW and the beam is necessary. In this case, observed enhancements in the bending stiffness were up to $46 \%$, and load-carrying capacity increased by $11 \%$. Gaff et al. (2015a) consider that sandwich materials made of wood have better bendability when a soft material is placed in its bottom layer. The bendability coefficient depends on the layer's position and its thickness in the composite.

The bending ability of glued beams was also examined in the study by Ruman et al. (2017). The study examined the influence of wood species, lamella combination, type of adhesive, number of loading cycles on the deflection at the proportionality limit, deflection at the point rupture, and the ratio between the deflection at the proportionality limit and the deflection at the point of rupture in laminated wood. The results showed the most significant effects on the deflection at the proportionality limit. Thicker material can achieve a higher proportion of plastic deformation and is more suitable for molding by bending. Research was also conducted on strengthening of structures made of bamboo using thin layers of strips of young bamboo stalks (Penellum et al. 2018).

Moreover, bamboo products can be reinforced with a bamboo net, which significantly increases the stiffness and strength of structures compared to traditional wood materials (Sharma et al. 2015; Zhong et al. 2017). The research carried out by Fang et al. (2015) shows that the increase in the thickness of bamboo and glass-fiber-reinforced polymer layers significantly affects the bending stiffness and the maximum load on the laminated beams. The study by Manalo et al. (2010) illustrates the strength and stiffness of composites made with the beams' flatwise and edgewise positions. Using the same amount of material, beams in the edgewise position could offer a $25 \%$ increase in strength compared to beams in the flatwise position. An attractive solution is strengthening multilayer beams by connecting individual layers with dowels (Loinsigh et al. 2012; Reynolds et al. 2016). New wood-based sandwich structures (plywood core and skins made either of aluminum or fiber-reinforced polymer: carbon, glass, or flax composite skins) showed that the plywood-carbon composite skins solution is the best in terms of stiffness (almost three times better than the reference aramid honeycomb-carbon and glass material) (Susainathan et al. 2017, 2018).

A separate and significant research area is searching for lightweight laminated cellular boards made of wood and plywood. New composites have strength similar to traditional plywood, but even 45\% less weight (Labans and Kalnins 2014). So panels with plywood facings and different types of the core, for example: corrugated (Kavermann and Bhattacharyya 2019), with auxetic oval cells (Smardzewski 2019a) or auxetic cells in the form of arrows (Smardzewski $2019 b$ ) were designed. Testing of the sandwich panel made of okoumé plywood skins bonded to an innovative honeycomb core constituted by lozenge-shaped okoumé plywood cells showed that the composite turned out extremely light (with a density of $205 \mathrm{~kg} / \mathrm{m}^{3}$ ). The composite's physical-mechanical properties meet requirements in terms of bending strength, modulus of elasticity, shear strength, traction perpendicular to faces, and dimensional stability (Negro et al. 2011). Labans et al. (2017) showed that sandwich panels with wood, plywood, foams, and thermoplastic composite core showed sufficient mechanical characteristics to be suitable for floor and wall unit implementation. Compared to a solid plywood board, sandwich-developed panels can reach up to $42 \%$ higher specific stiffness while maintaining sufficient strength characteristics. Sandwich panels of pinewood veneer and a core of cork also show similar mechanical properties. In this way, Lakreb et al. (2015) developed natural-based products with a low ecological footprint and favorable production costs. Increasing the number of layers in the sandwich panel improved the strength of the material. According to Smardzewski and Jasińska (2016), wood-based sandwich panels with a wavy core can sustain higher loads than similar honeycomb structures because they have the shape of core cells that guarantees minimal displacements and high strength. Hayashi et al. (2003) designed MDF panels reinforced corrugated particleboards. The composite is a lightweight material with a density of $480 \mathrm{~kg} / \mathrm{m}^{3}$ and a strength equivalent to particleboard. 
Further decreasing wood composites' density has led to manufacturing the honeycomb cores from paper. The testing of sandwich panels containing kraft paper honeycomb core and wood composite facings showed that the sandwich panel's flexural creep behavior is affected by the honeycomb core shape, core and facings thickness, and facings material type (Chen et al. 2011). Hao et al. (2018) explained that the Taiji honeycomb structure has 3.5 times the compression and shear strength of commercial hexagonal ones. Using this type of core in wooden sandwich composite resulted in an increase in compression and shear strength by 1.75 times. The reinforcement of the core also results in an almost linear increase in the sandwich composite's strength. Smardzewski (2013) showed that honeycomb wood panels with paper auxetic core exhibited higher rigidity than panels with hexagonal cell core. Manufactured panels are also characterized by high orthotropic properties.

More and less simplified analytical or numerical models have also been developed to assess the bending behavior of wooden structural panels (Banerjee and Bhattacharyya 2011; Zhang et al. 2015; Li et al. 2016). They give the possibility of a balanced approach to the design of light wooden structural panels.

Lightweight in the wood-based construction and furniture industry is not a new topic. The density reduction using a sandwich structure with light cores for doors or mobile homes was confirmed by users more than five decades ago. However, the literature review shows that the cellular structure has always been associated with sandwich panels and has not been explored enough as an independent structural form. Production of openwork wooden panels is described in the paper by Skuratov (2010). The developed wooden panel features low-quality wood sufficiency for the building industry needs and low waste levels. The production of one cubic meter of panel requires a little more than $1 \mathrm{~m}^{3}$ of dry timber. Thanks to the openwork surface, panels have low density $\left(300-350 \mathrm{~kg} / \mathrm{m}^{3}\right)$ and good mechanical properties, close to known solid wood panels. A similar type of openwork panel made of curvilinear wooden slats that form a hexagonal mesh was designed by Murlak (2019) and registered with the Patent Office of the Republic of Poland (Fig. 1).

Taking into account the above considerations, it was decided to verify the research hypothesis that openwork solid wood panels show high stiffness and strength, similar to solid wood panels. Therefore, the undertaken research aimed to determine the influence of the wood species and the inclination angle of the inner walls of inclusions on the stiffness, strength, and ability to absorb energy of the new type of openwork panel manufactured from curvilinear wooden slats, designed by Murlak (2019).
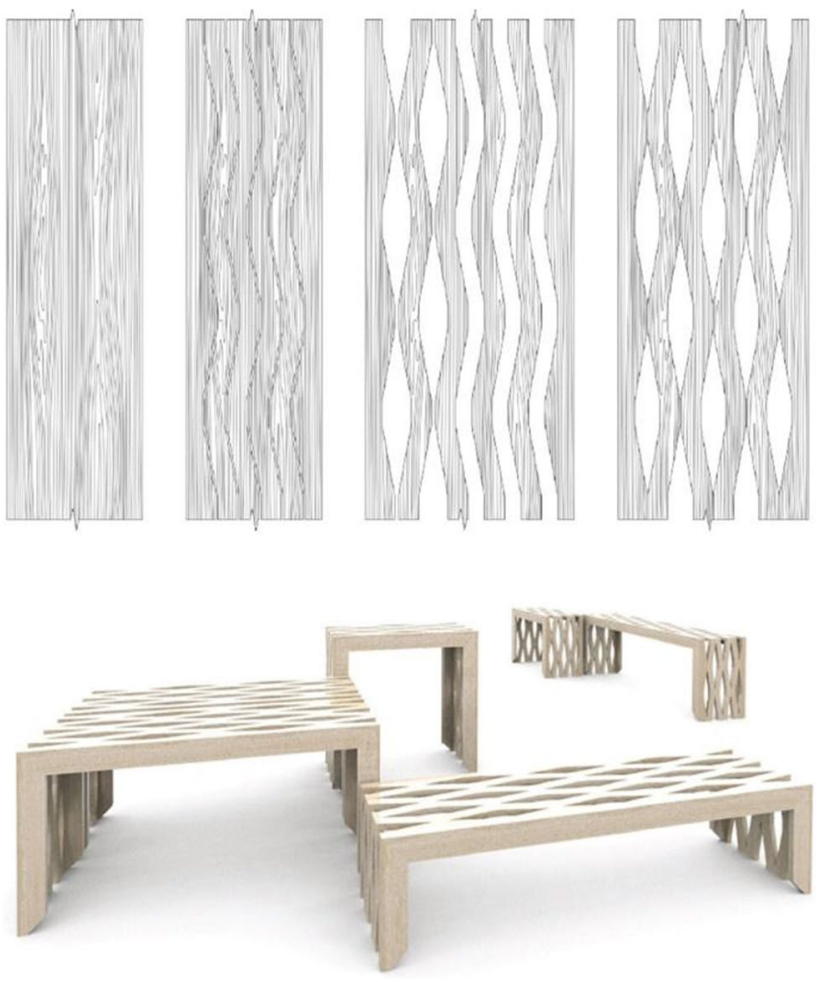

Fig. 1 Idea of production and use of openwork panels for furniture design

\section{Materials and methods}

\subsection{Panels design and fabrication}

Taking into account the shape and dimensional proportions of the structures designed by Murlak (2019) (Fig. 1), the tests were carried out on solid and openwork panels with a thickness and length of 18 and $1032 \mathrm{~mm}$, respectively (Fig. 2). The solid panels were made of $265 \mathrm{~mm}$ wide solid timber (not glued) with fibers oriented along the longer side of the panel. The openwork panels were made by gluing together six curvilinear slats cut from $265 \mathrm{~mm}$ wide solid panels. According to Kollmann and Cote (1968), the bending strength of the curvilinear wood elements depends, among others, on the inclination of the wood fibers to the beam axis. This inclination should not exceed $10^{\circ}$. Therefore, in further considerations, it was assumed that the inclination of the side walls of the curvilinear slats to the longer side of the panel equals $9^{\circ}$ and $11^{\circ}$. This way, the width of the openwork panels was increased to 328 and $355 \mathrm{~mm}$, respectively. Thus, the width of the openwork panel compared to the width of the solid panels increased by 63 and $90 \mathrm{~mm}$, respectively (Fig. 2). The authors decided to make the panels following the patent claim P.42481 (Murlak 2019). So, the side walls of the curvilinear slats to the longer side of the panel are considered for two cases only. The panels were 

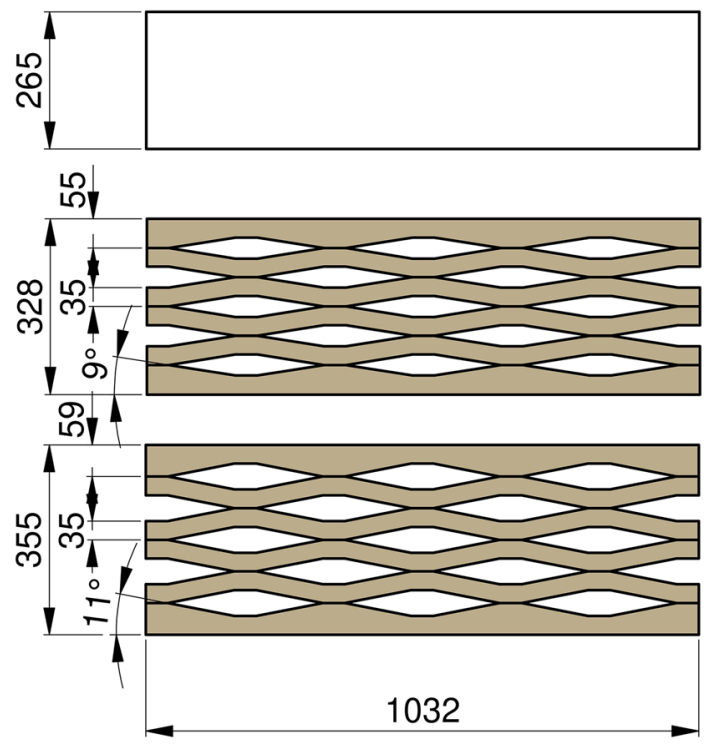

Fig. 2 Dimension of solid and openwork panels with inclination angle $9^{\circ}$ and $11^{\circ}$, respectively

made of beech (Fagus sylvatica L.), oak (Quercus robur L.), ash (Fraxinus excelsior L.), and walnut (Juglans regia $\mathrm{L}$ ). The basic physical and mechanical properties of the selected wood species are presented in Table 1.

At first, the boards of $20 \mathrm{~mm}$ thickness were planed on both sides on a Format 4 planer (Felder Group, Żory, Poland) in order to obtain a constant thickness of $18.2 \mathrm{~mm}$. Then, solid full panels and curved slats were made on the Infotec Professional milling plotter (InfoTEC CNC, Zasutowo, Poland), using a $3 \mathrm{~mm}$ end mill operating at a speed of 24,000 rpm (Fig. 3). All elements were sanded on a DMC MB 90 wide-belt sander (SCM Polska SP.Z.O.O., Suchy Las near Poznań, Poland) to a thickness of $18 \mathrm{~mm}$. Curvilinear slats were glued with Chemolan B 4 M/D4 polyurethane adhesive (Interchemol S.A., Oborniki Sląskie, Poland). Based on previous experimental studies, an adhesive linear elasticity modulus of $820 \mathrm{MPa}$ and shear strength of $16 \mathrm{MPa}$ were assumed (Kamboj et al. 2020). The adhesive was applied on flat, rectangular surfaces with dimensions of $18 \mathrm{~mm} \times 41 \mathrm{~mm}$ (Fig. 4). After applying a pressure of $0.3 \mathrm{MPa}$, the panels were left in the laboratory for 28 days for air conditioning. The relative air humidity and temperature in the laboratory room were $65 \pm 1 \%$ and $21 \pm 1{ }^{\circ} \mathrm{C}$, respectively. Under those conditions, the wood reached the hygroscopic equilibrium without changing its absolute humidity. After seasoning, an average thickness of $0.1 \mathrm{~mm}$ of the adhesive layer was measured using a Kern OZM 922 microscope (KERN \& Sohn GmbH, Balingen, Germany).

Table 2 presents the mass and volume of the designed panels, based on the density of wood presented in Table 1 . The table shows that the volume of the openwork panel with the $9^{\circ}$ and $11^{\circ}$ inclination angle of the side walls is smaller by 10 and $8.2 \%$, respectively, in relation to the solid panel.

\subsection{Experiments}

Five identical solid and openwork panels with an inclination angle of the side wall of $11^{\circ}$ were made from each wood species for the experimental tests. The panels were subjected to three-point bending on a Zwick 1445 universal testing machine (Zwick Roell GmbH \& Co. KG, Ulm, Germany) (Fig. 5). For the bending tests, a support spacing of $800 \mathrm{~mm}$ was used. It is a representative dimension for shelves and top and bottom panels used in furniture design. The panel length of $1032 \mathrm{~mm}$ was due to technological limitations arising during formatting on a sawing machine. During the tests, the force was recorded with an accuracy of $0.01 \mathrm{~N}$ and the displacement in the direction of the force with an accuracy of $0.01 \mathrm{~mm}$. The speed of increasing the displacement was set at $10 \mathrm{~mm} / \mathrm{min}$, according to EN 310 standard (EN 310:1993 1993). It was assumed that the structure produced is a type of wood composite. The tests were stopped when the panel deflection of $40 \mathrm{~mm}$ was obtained. The limitation resulted from preliminary tests, which revealed high susceptibility of the panels to bending without damage (even up to $60 \mathrm{~mm}$ ). Moreover, for aesthetic reasons, deflections of furniture elements exceeding $4 \mathrm{~mm} / \mathrm{m}$ are considered unacceptable (Smardzewski 2015).

Based on the direct results of experimental tests, the interdependencies between the load and deflection of the panels were determined. These dependencies were used to calibrate analogical numerical models. As a consequence of the satisfactory accordance between the results of experimental tests and numerical calculations for solid and openwork panels with an inclination angle of the side
Table 1 Elastic and physical properties of selected wood species (Kollmann and Cote 1968; Cai and Ross 2010; Smardzewski 2015)

\begin{tabular}{llllllllllll}
\hline Type of wood & $\begin{array}{l}E_{L} \\
\mathrm{MPa}\end{array}$ & \multicolumn{1}{l}{$E_{R}$} & \multicolumn{1}{c}{$E_{T}$} & $G_{L R}$ & $G_{L T}$ & $G_{R T}$ & $\vartheta_{L R}$ & $\vartheta_{L T}$ & $\vartheta_{R T}$ & $\begin{array}{l}\text { MOR } \\
\mathrm{MPa}\end{array}$ & $\begin{array}{l}\text { Density } \\
\left(\mathrm{kg} / \mathrm{m}^{3}\right)\end{array}$ \\
\hline Beech & 13,969 & 2284 & 1160 & 1645 & 1082 & 471 & 0.450 & 0.510 & 0.750 & 102 & 721 \\
Walnut & 13,760 & 1372 & 714 & 1084 & 791 & 267 & 0.495 & 0.632 & 0.718 & 100 & 609 \\
Ash & 13,200 & 1650 & 1056 & 1438 & 1016 & 1016 & 0.371 & 0.440 & 0.684 & 103 & 673 \\
Oak & 12,530 & 2205 & 2205 & 1163 & 1163 & 470 & 0.369 & 0.428 & 0.618 & 104 & 769 \\
\hline
\end{tabular}




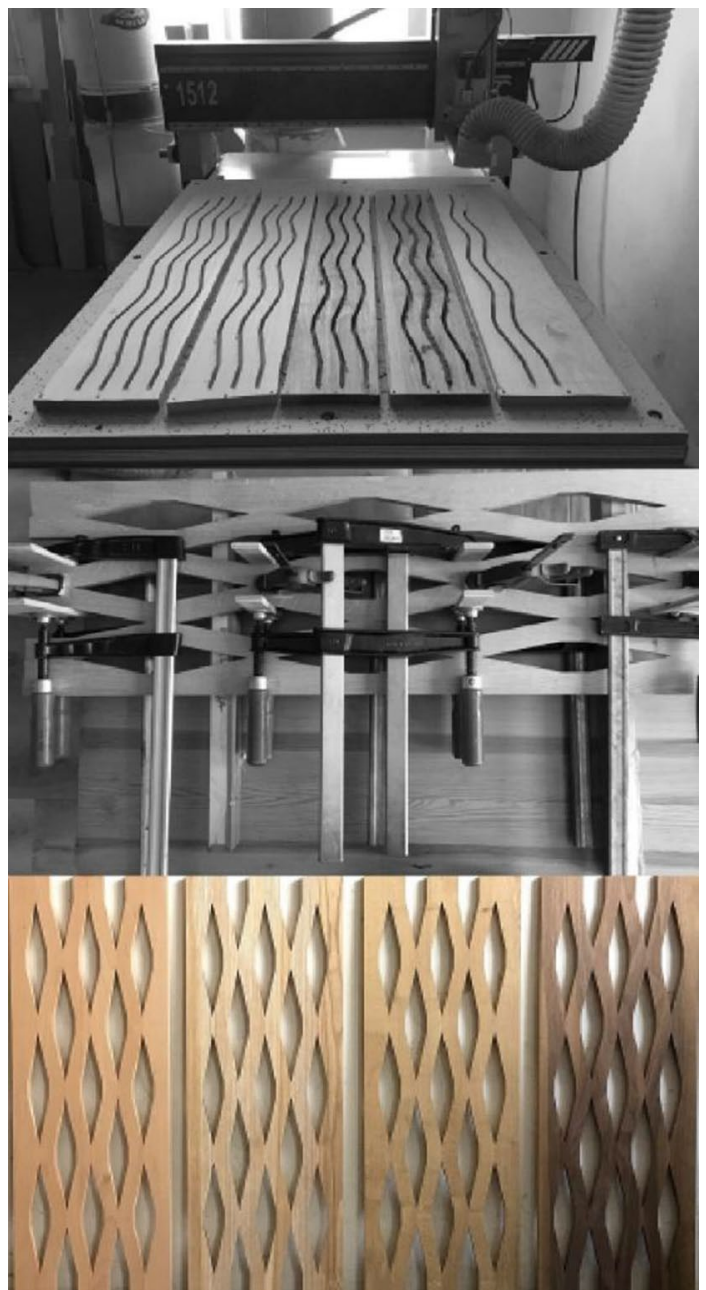

Fig. 3 Production of openwork panels

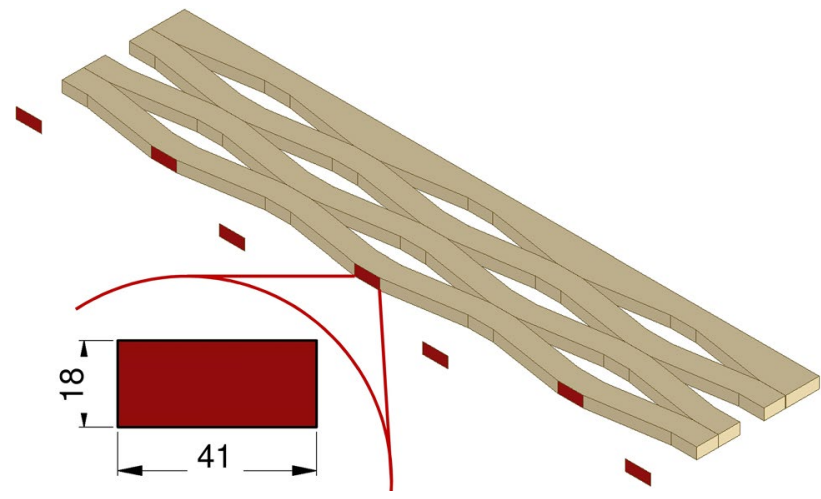

Fig. 4 Openwork panels with a glue line

walls of $11^{\circ}$, an additional numerical model of the openwork panel with an inclination angle of the side walls of $9^{\circ}$ was developed, which was smaller by $1^{\circ}$ from the $10^{\circ}$
Table 2 Volume and mass of selected types of panels

\begin{tabular}{llll}
\hline Type of wood & Mass $(\mathrm{kg})$ & $\begin{array}{l}\text { Inclination } \\
\text { angle }\left(^{\circ}\right)\end{array}$ & Volume $\left(\mathrm{m}^{3}\right)$ \\
\hline Beech & 3.0854 & 9 & $427.93 \times 10^{-5}$ \\
Oak & 3.2908 & & \\
Ash & 2.8800 & & \\
Walnut & 2.6061 & & $436.54 \times 10^{-5}$ \\
Beech & 3.1475 & 11 & \\
Oak & 3.3570 & & $492.26 \times 10^{-5}$ \\
Ash & 2.9379 & & \\
Walnut & 2.6585 & & \\
Beech & 3.4287 & Solid & \\
Oak & 3.6569 & & \\
Ash & 3.2004 & & \\
Walnut & 2.8961 & & \\
\hline
\end{tabular}

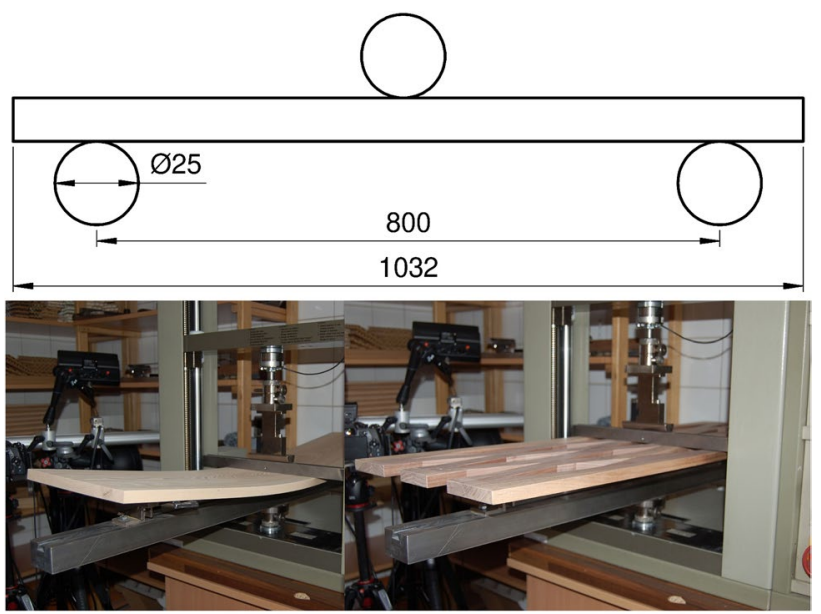

a)

b)

Fig. 5 Bending test of solid (a) and openwork panels (b) with inclination angle $11^{\circ}$

value suggested in the literature, and smaller by $2^{\circ}$ from the experimental model. Table 3 shows the markings of all test samples. Additionally, Table 4 presents the characteristics of the cross-sections of the bent panels.

The next stage of the research was to determine the energy absorbed during the bending of the panels. Energy absorption is key to testing the structural integrity in the event of failure. As shown in some articles (Jin et al. 2015; Yan et al. 2014; Schneider et al. 2016; Sun et al. 2017; Yazdani Sarvestani et al. 2018; Smardzewski 2019b; Ha and Lu 2020; Farrokhabadi et al. 2020), the honeycomb panels exhibit excellent energy absorption properties. The energy absorption $E_{a}(\mathrm{~J})$ of the selected panels was calculated as follows: 
Table 3 Symbols of selected samples and tests

\begin{tabular}{llll}
\hline Type of wood & Inclination angle $\left(^{\circ}\right)$ & Symbol & \\
\cline { 3 - 4 } & & Experiment & $\begin{array}{l}\text { Numerical } \\
\text { calculation }\end{array}$ \\
\hline Beech & 9 & & B9-N \\
Oak & & & O9-N \\
Ash & & & A9-N \\
Walnut & & B11 & W9-N \\
Beech & 11 & O11 & O11-N \\
Oak & & A11 & A11-N \\
Ash & & W11 & W11-N \\
Walnut & & BS & BS-N \\
Beech & Solid wood & OS & OS-N \\
Oak & & AS & AS-N \\
Ash & & WS & WS-N \\
Walnut & & &
\end{tabular}

$E_{a}=\int_{0}^{d_{\max }} F_{x} d x$

where $F_{x}(\mathrm{~N})$ is the crushing force as a function of displacement $x(\mathrm{~m})$ during the crushing process, $d_{\max }(\mathrm{m})$ is the effective deformation distance (deflection). The next parameter for analysis was specific energy absorption by panels per unit mass given by:

$S E_{a}=\frac{\int_{0}^{d_{\max }} F_{x} d x}{m}$,

where $S E_{a}(\mathrm{~J})$ is specific energy absorption, $m$ is the mass of the energy absorber. $S E_{a}$ is often used to compare the energy-absorbing ability of different materials and structures. The average crushing force $F_{c}(\mathrm{~N})$ was defined as follows:

$F_{c}=\frac{\int_{0}^{d_{\max }} F_{x} d x}{l}$,

where $l(\mathrm{~m})$ is the displacement corresponding to the maximum load, $F_{x}(\mathrm{~N})$ is the instantaneous compression force.

\subsection{Numerical models of panels}

Figure 6 presents models for numerical calculations of solid and openwork panels composed of 223,507 nodes and 174,804 elements (average), including quadrilateral elements of type R3D4, linear hexahedral elements of type C3D8R, and COH3D8 cohesive elements. Type R3D4 elements were used to model supports, type C3D8R elements for modeling wood, and COH3D8 for glue line. The numerical model of wooden elements was described with the use of the orthotropy plasticity material model (Kawashita et al. 2012; Qiu et al. 2014; Tran et al. 2015; Smardzewski 2019a). In the cited articles, the non-linear elastic properties of wood have been pointed out many times. Therefore, in this study, nonlinear models were also used, both due to the orthotropy of the wood as well as the geometric nonlinearity of the model. The material constants are shown in Table 1, and the directions of the orthotropy are presented in Fig. 6, where L, R,
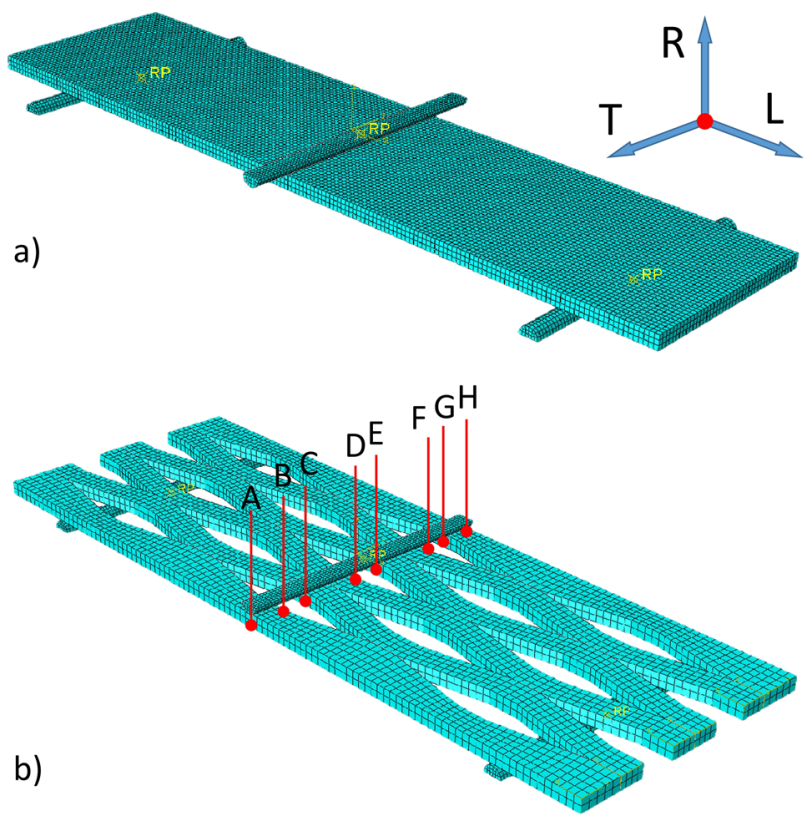

Fig. 6 Numerical model of solid (a) and openwork panels (b). Points A, B, C, D, E, F, G, H illustrate places for normal stress control
Table 4 Characteristics of panel cross-sections

\begin{tabular}{cccc}
\hline Panel & Cross-sectional & \multicolumn{2}{c}{ Moment of inertia $\left(\mathbf{m}^{4}\right)$} \\
\cline { 3 - 4 } type & area $\left(\mathbf{m}^{2}\right)$ & $I_{x}$ & $I_{y}$ \\
\hline Solid & $4.770 \cdot 10^{-3}$ & $128.790 \cdot 10^{-9}$ & $25.165 \cdot 10^{-6}$ \\
$9^{\circ}$ & $3.783 \cdot 10^{-3}$ & $102.157 \cdot 10^{-9}$ & $35.790 \cdot 10^{-6}$ \\
$11^{\circ}$ & $3.783 \cdot 10^{-3}$ & $102.157 \cdot 10^{-9}$ & $42.235 \cdot 10^{-6}$ \\
\hline
\end{tabular}


T show anatomical directions of wood: longitudinal, radial, and tangential, respectively. A glue line joined the slats. The behavior of glue lines was modeled using the Cohesive Zone Model (CZM) through standard COH3D8 cohesive elements. The cohesive stiffness was estimated from the glue line isotropic mechanical properties (Smardzewski 2019a; Kamboj et al. 2020), assuming that the interfacial stiffness represents the elastic deformation of a glue-line layer of $0.1 \mathrm{~mm}$ in thickness. The panels were supported and loaded similarly, as shown in Fig. 5. The fixed supports and crosshead were assumed as perfectly rigid bodies. Between them and the panels, a surface-to-surface contact with a friction coefficient of 0.2 was modeled. The crosshead movement controlled the load value, causing the sample to be deflected by $40 \mathrm{~mm}$ at half its length.

Prior to starting numerical calculations, the models were first calibrated by selecting the appropriate mesh density and the number of iterations to obtain a satisfactory agreement between the load-deflection relationships determined numerically and in experimental tests. The calibration was finished successfully when the results were achieved, with no more than a $5 \%$ difference. The stresses at the wooden slats' A-H points were then calculated (Fig. 6a). Stresses in the glue line were also calculated (Fig. 4), and then, using Eqs. 1-3, the absorbed energy, specific energy absorption, and crushing force were calculated. Figure 7 shows examples of deflections and stresses distribution in bending panels.

The commercial ABAQUS/Explicit v. 6.14 software (Dassault Systemes Simulia Corp., Waltham, MA, USA) was used for numerical calculations. All computations were performed at the Poznan Supercomputing and Networking Center (PSNC) using the Eagle computing cluster.

\section{Results and discussion}

\subsection{Effect of inclination angle on stiffness and strength of panels}

Figure 8a shows the average values for the experimental dependence between the load and deflection of the bent panels. This figure shows that for the same deflection value of $40 \mathrm{~mm}$, the maximum forces are greater for solid panels and smaller for openwork panels. For solid panels made of beech, walnut, ash, and oak wood, the maximum bending forces are equal to $2983 \mathrm{~N}, 2935 \mathrm{~N}, 2842 \mathrm{~N}$, and $2455 \mathrm{~N}$, respectively. The decreasing values of bending forces result from decreasing values of linear elasticity modulus for selected wood species, 13,969 MPa, 13,760 MPa, 13,200 MPa, and $12,530 \mathrm{MPa}$, respectively (Table 1 ). For openwork panels with an $11^{\circ}$ inclination angle of side walls made of beech, walnut, ash, and oak wood, the maximum bending forces are respectively lower by $12.3 \%, 3.4 \%, 22.5 \%$ and $13.0 \%$. The obvious reason for the lower values of bending forces of openwork panels is their $20.6 \%$ lower moment of inertia of the $I_{x}\left(\mathrm{~m}^{4}\right)$ cross-section compared to the moment of inertia of the solid panels' cross-section (Table 4). However, what is interesting is that in the case of walnut wood, the stiffness of the solid panels was only $3.4 \%$ higher compared to the openwork panels, and in the case of ash wood, this difference
Fig. 7 Example of numerical calculation of solid (a) and openwork panels (b)
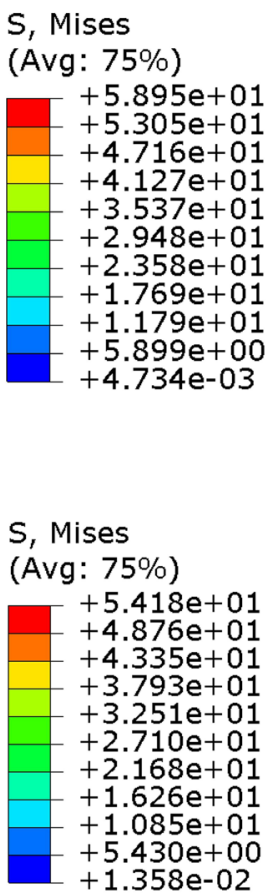
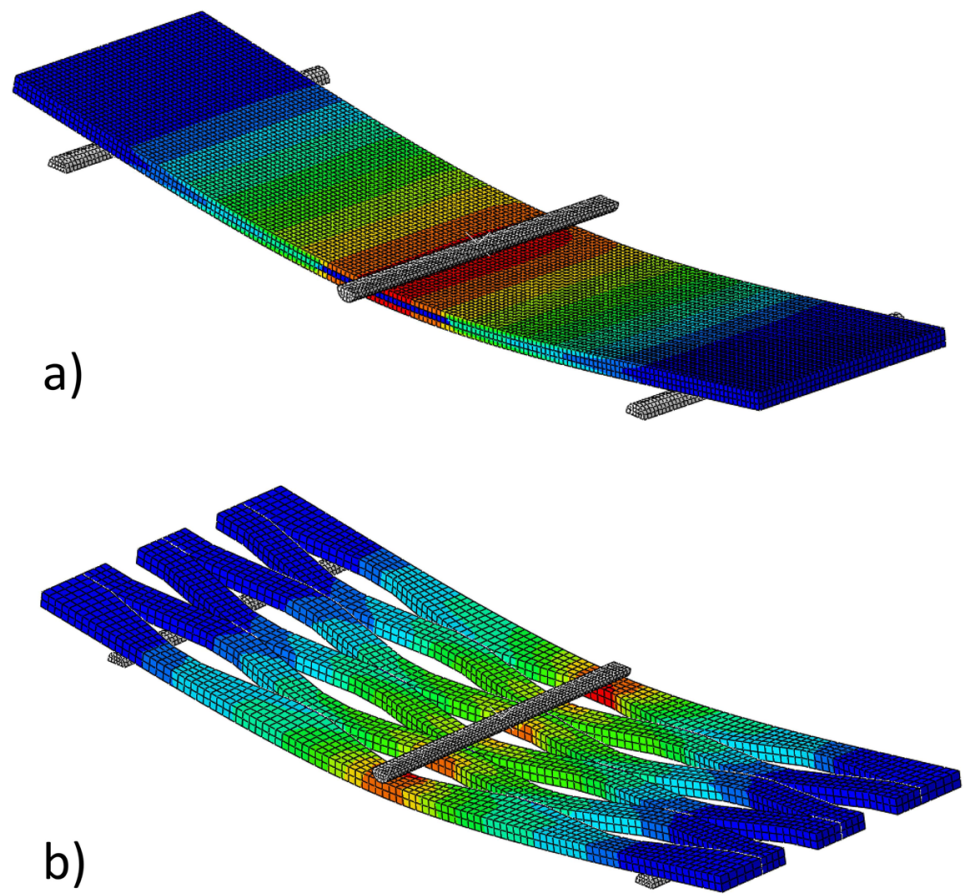
Fig. 8 Relationship between load and deflection of solid and openwork panels for the experimental test (a), and the numerical calculation (b), where BS, OS, AS, WS are solid beech, oak, ash, walnut panels, and B11, O11, A11, W11 openwork beech, oak, ash, walnut panels with inclination angle $11^{\circ}$, respectively, $N$ results of numerical calculation
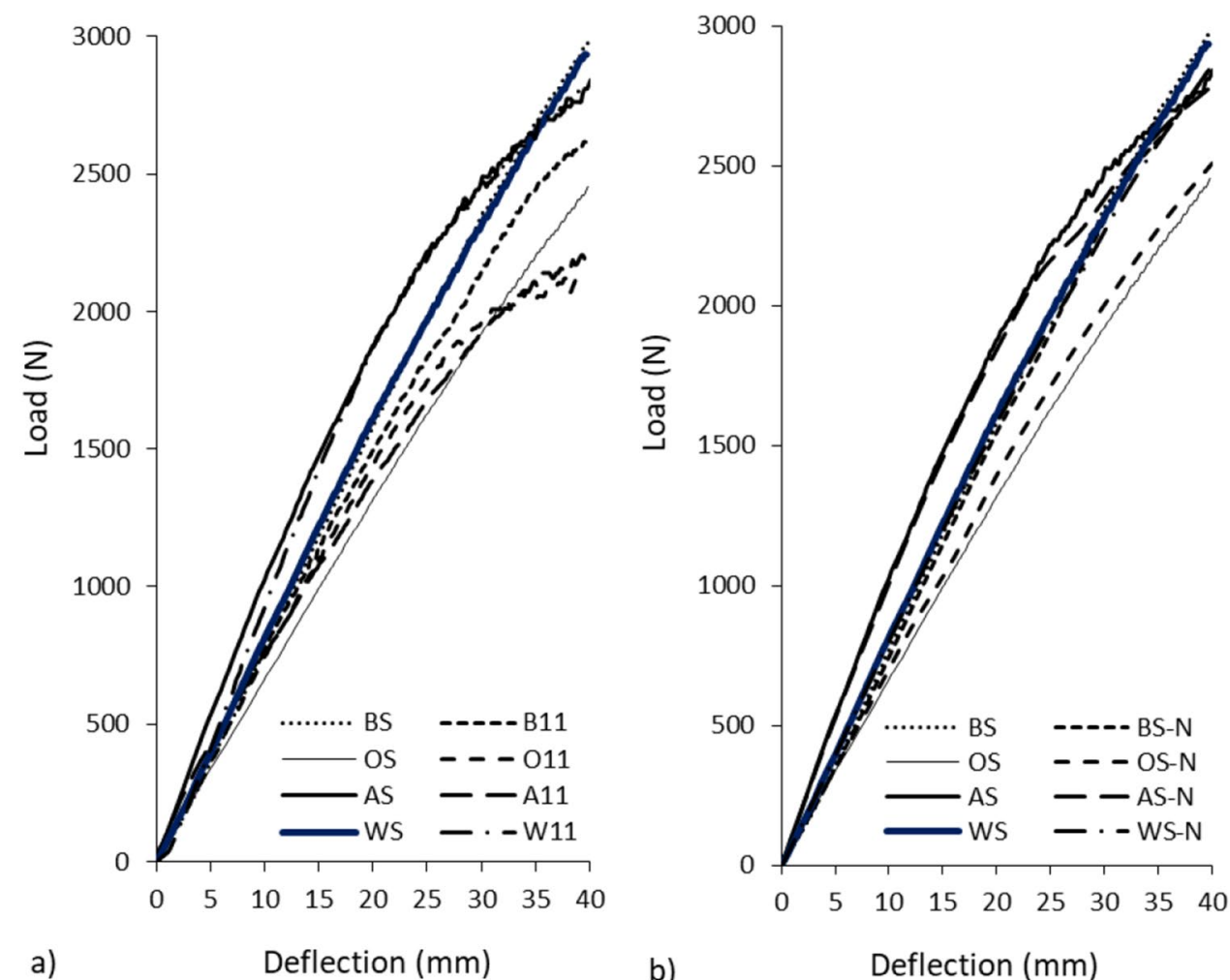

a)

Deflection $(\mathrm{mm})$ b) equaled $22.5 \%$. This may give preference to walnut wood and limit the use of ash wood as a raw material for making openwork panels. Figure $8 \mathrm{~b}$ shows the results of numerical calculations for analogically loaded solid and openwork panels with an $11^{\circ}$ angle of inclination of the side walls. This figure shows that for a deflection of $40 \mathrm{~mm}$, the maximum forces for solid panels made of beech, walnut, ash, and oak wood equal to $2861 \mathrm{~N}, 2858 \mathrm{~N}, 2787 \mathrm{~N}$, and $2508 \mathrm{~N}$, respectively, whereas for openwork panels with an $11^{\circ}$ inclination angle of the walls, the maximum bending forces are respectively lower by $7.7 \%, 5.6 \%, 17.1 \%$ and $13.9 \%$. Thus, Fig. 8 shows that the results of numerical calculations are accordant with the results of the experimental studies. The differences between the values of experimental bending force for solid panels equal 4.1\%, 2.6\%, 1.9\%, 2.2\% for beech, walnut, ash, and oak, respectively. However, the differences for openwork panels equal $0.1 \%, 6.3 \%, 3.4 \%, 0.2 \%$ for beech, walnut, ash and oak wood, respectively.

To fully illustrate the satisfactory consistency of the numerical calculations with the results of laboratory tests, not only in relation to the values of maximum forces but also in terms of the load-deflection relationship, Fig. 9 compares the curves determined experimentally and numerically. This figure clearly shows that the curves determined numerically correspond satisfactorily with the experimental curves. Therefore, it was concluded that the calibration of the numerical model was carried out correctly, and the results of the numerical calculations could be used in the further argument. On this basis, numerical calculations were carried out for openwork panels with a $9^{\circ}$ inclination angle of the side walls. Figure 10a summarizes the load-deflection relationships for openwork panels, while Fig. 10b shows the values of the maximum forces causing a deflection of $40 \mathrm{~mm}$ for solid and openwork panels.

Figure 10a shows that the load-deflection curves for openwork panels with $9^{\circ}$ and $11^{\circ}$ inclination angles of the side walls coincide. In contrast, Fig. $10 \mathrm{~b}$ shows that the values of maximum forces causing deflection of these panels are minor and do not exceed $37 \mathrm{~N}$. Of course, there is a significant difference between the values of the maximum forces causing bending of solid and openwork panels. In the case of panels with an $11^{\circ}$ inclination angle of the side walls, the maximum forces are lower by $8.5 \%, 6.9 \%, 18.3 \%$, and $15 \%$, respectively, for beech, walnut, ash, and oak, and for panels with an inclination angle of $9^{\circ}$ equal to $7.7 \%, 5.6 \%$, $17 \%$, and $14 \%$.

The presented results show that making openwork panels out of solid panels with an inclination angle of the side walls $9^{\circ}$ and $11^{\circ}$ reduces their stiffness from 7.7 to $18.3 \%$. At the same time, a minor decrease in stiffness was recorded for openwork panels made out of walnut wood (from 5.6 to $6.9 \%$ ). Therefore, it is recommended to produce openwork panels from walnut, and then beech and oak wood, preferring the $11^{\circ}$ angle of inclination of the side walls, which ensures the greatest width of the panel. 
Fig. 9 Relationship between load and deflection. Comparison results of the numerical calculation and experimental test for solid (a), and openwork panels (b), where BS, OS, AS, WS are solid beech, oak, ash, walnut panels, and B11, O11, A11, W11 openwork beech, oak, ash, walnut panels with inclination angle $11^{\circ}$, respectively, $N$ results of numerical calculation

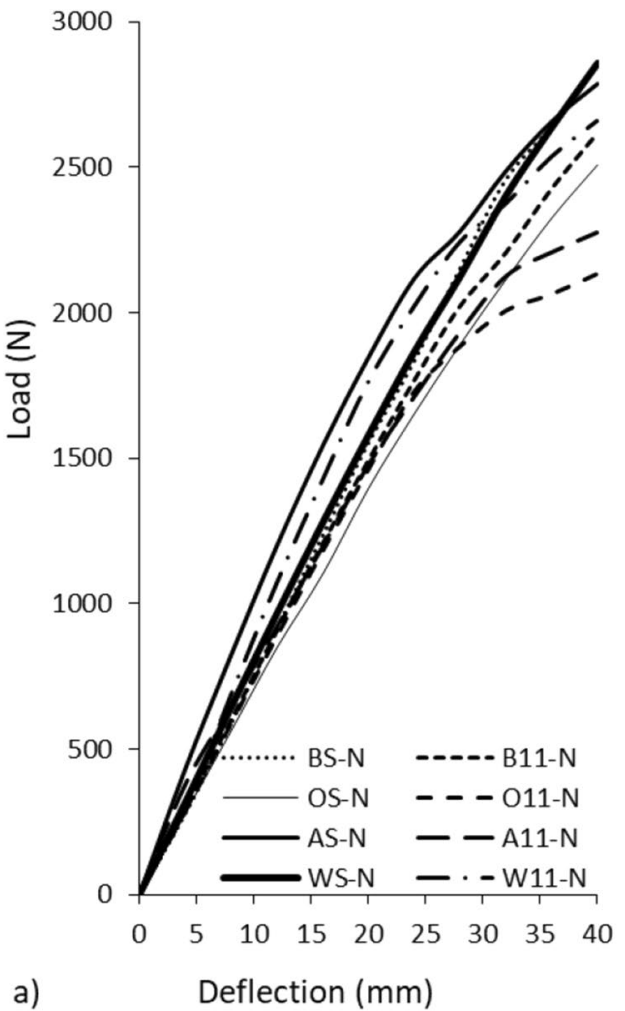

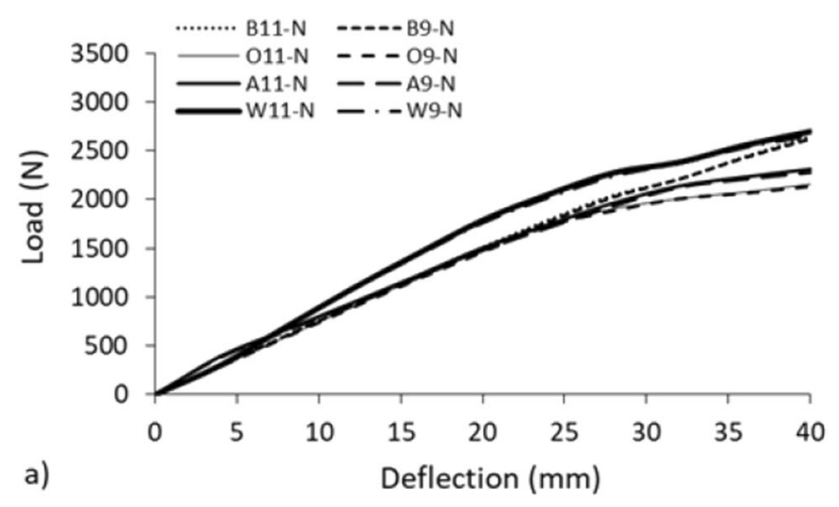

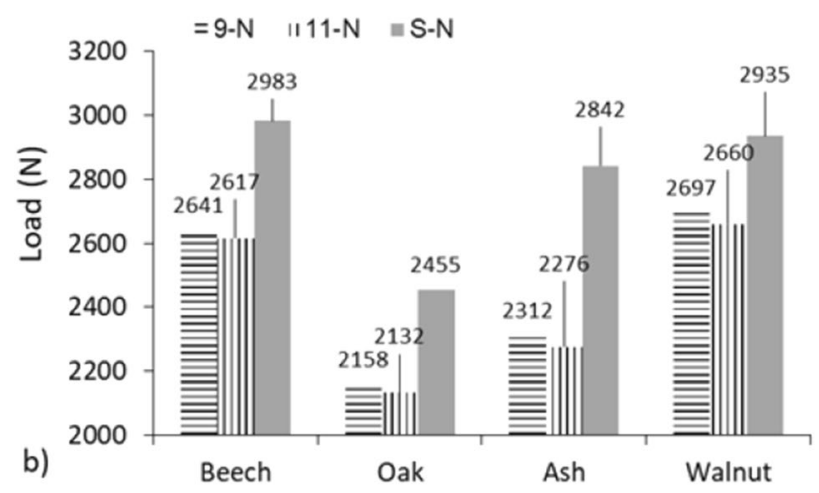

Fig. 10 Relationship between load and deflection-comparison results of the numerical calculation for openwork panels with inclination angle $9^{\circ}$ and $11^{\circ}$, where $\mathrm{B}, \mathrm{O}, \mathrm{A}, \mathrm{W}$, respectively beech, oak, ash, walnut (a), and maximum load under panels bending, where $\mathrm{S}$ solid panels (b)
Table 1 shows that the difference between the greatest modulus of elasticity $E_{L}$ of beech and the walnut, ash, oak is equal to $2 \%, 6 \%$, and $11 \%$, respectively. For $E_{R}$ and $E_{T}$ modules it is $66 \%, 38 \%, 4 \%$ and $62 \%, 10 \%, 45 \%$, respectively. The difference of the maximal forces causing the beech sample $\left(9^{\circ}\right.$ and $\left.11^{\circ}\right)$ to deflect by $40 \mathrm{~mm}$ compared to the other samples is equal to $2 \%, 15 \%$, and $23 \%$, respectively. This regularity illustrates that the panel stiffness increases with an increase in the modulus of linear elasticity of the wood. At the same time, the differences between linear modules of wood elasticity and the differences between the bending forces of panels are adequate to each other. The orthotropic nature of wood and differences between the modules of wood elasticity across the grain also significantly influence the measured forces.

The differences in the strength of the designed and manufactured panels are interesting too. Figure $11 \mathrm{a}, \mathrm{b}$ shows the variation of normal stresses $\sigma_{z}(\mathrm{MPa})$ at points $\mathrm{A}-\mathrm{H}$ on the cross-section of the bent panel. This figure shows that the stresses in openwork panels have a non-linear course. Their value increases from the outer edges (points $\mathrm{A}$ and $\mathrm{H}$ ) towards the panel axis, reaching a maximum at points $\mathrm{B}$ and $\mathrm{G}$, which is on the inside of the first outer curvilinear slats. Then the stresses $\sigma_{z}(\mathrm{MPa})$ decrease and reach a minimum at points $\mathrm{D}$ and $\mathrm{E}$, near the middle slats' outer surfaces. The difference between the highest and the lowest normal stress does not exceed $10 \mathrm{MPa}$. At the same time, the maximum stresses (Fig. 11c) are significantly lower than the bending 

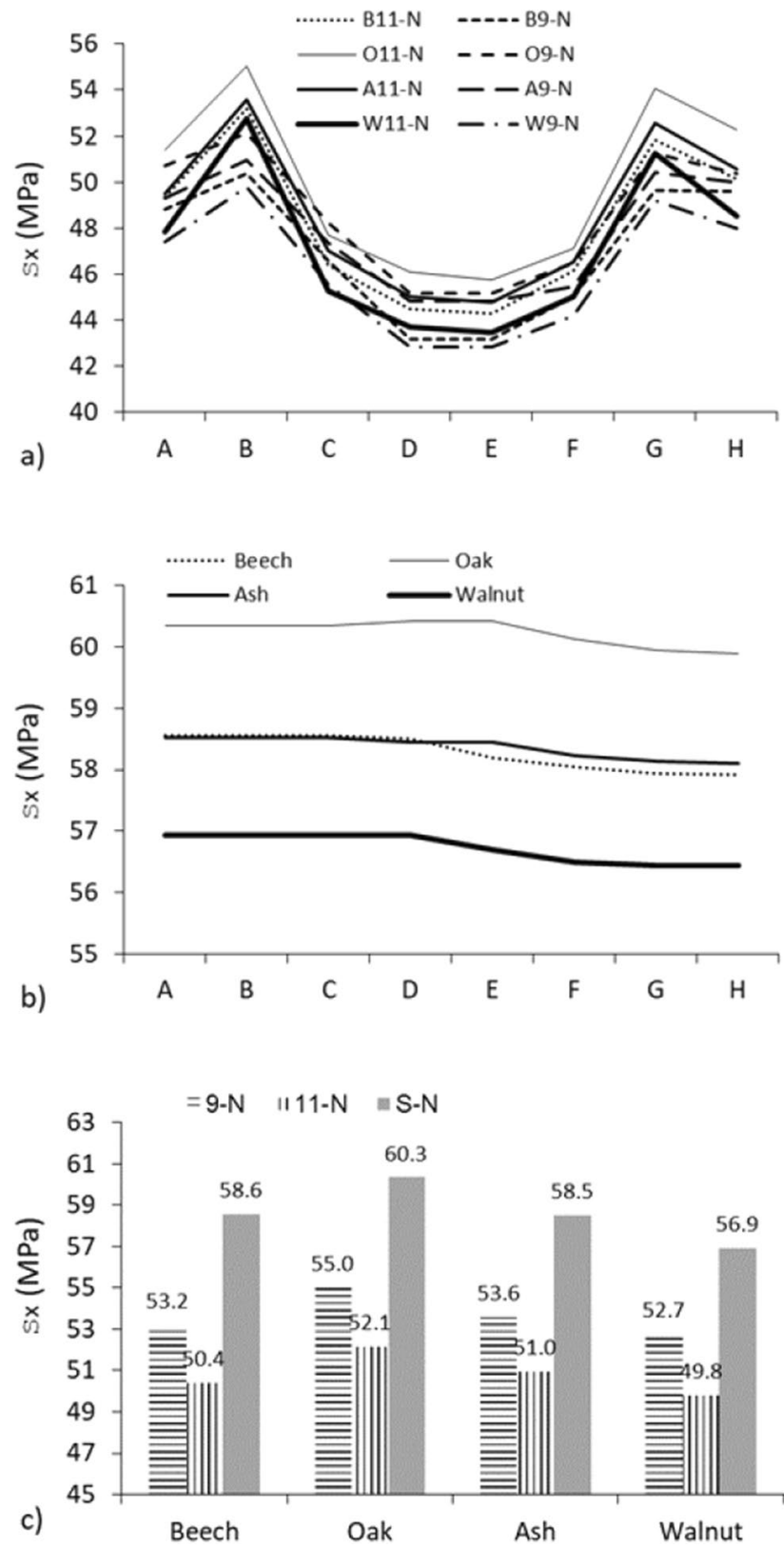

Fig. 11 Normal stress $\sigma_{z}$ distribution in selected points of openwork panels with inclination angle: $11^{\circ}$ and $9^{\circ}(\mathbf{a})$, solid panels (b), and maximal normal stresses $\sigma_{z}(\mathbf{c})$, where B11, O11, A11, W11 beech, oak, ash, walnut openwork panels with inclination angle $11^{\circ}$, B9, O9, A9, W9 beech, oak, ash, walnut openwork panels with inclination angle $9^{\circ}$, respectively, $N$ results of numerical calculation, $S$ solid panels

strength of the selected wood species (Table 1). In this case, the safety factor for wooden elements of openwork panels varies from 1.89 to 2.09. For solid panels (Fig. 11b), the $\sigma_{z}$ stresses (MPa) run almost linearly in the direction of the panel axis. As in the case of openwork panels, the maximum value of these stresses (Fig. 11c) does not exceed the bending strength of wood, which in this case is also manifested

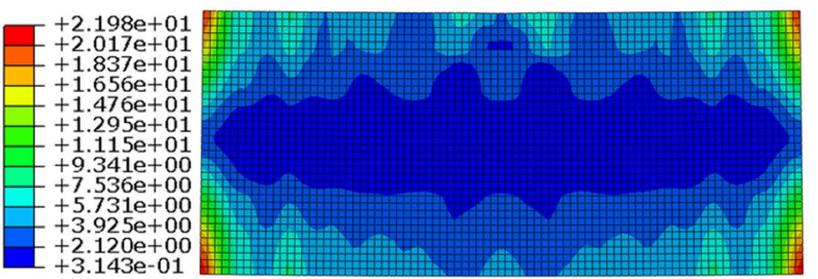

a)

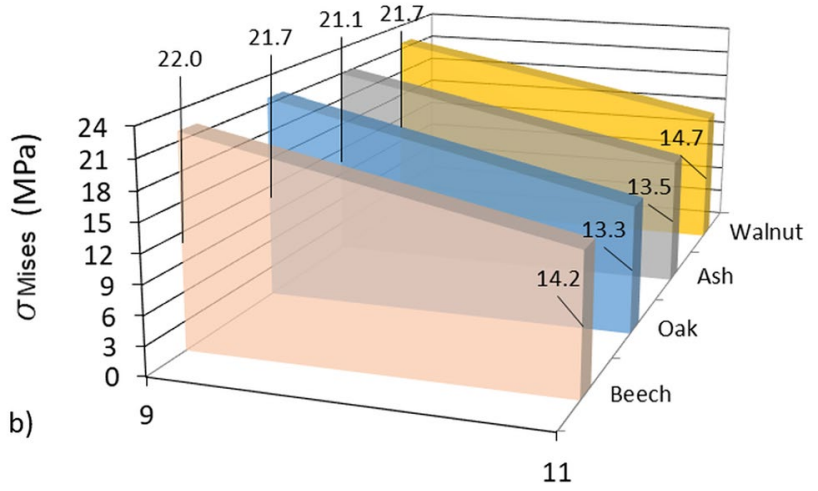

Fig. 12 Reduced (Von Mises) stresses in the glue line: stress distribution in glue line of openwork panel with inclination angle $9^{\circ}(\mathbf{a})$, and the effect of wood species and inclination angle on the maximum reduced stresses in the glue line (b)

by a high safety factor varying from 1.72 to 1.83 . This indicates that each proposed type of wood and each angle of inclination of the side walls in the openwork panels ensure good bending strength of the wooden slats.

In the performed tests, there is no detected failure in the slats. The main reason for this is the character of the test performed. In this case, bending deflection equal to $40 \mathrm{~mm}$ stopped the test. For this reason, the maximum stresses (Fig. 11c) are significantly lower than the bending strength of the selected wood species (Table 1).

Figure 12a shows the distribution of reduced stresses in the selected glue line, characteristic for all calculations (see Fig. 4). This illustration shows that the greatest stresses are concentrated in the corners of the glue line, and the smallest stresses close to zero value occur in the center of the surface of the glue line. This distribution is characteristic for adhesive and shape-adhesive corner joints subjected to bending (Smardzewski 1996, 2002, 2008; Imirzi et al. 2015). The scope of the cited works and the results of numerical calculations (Smardzewski 2019a, b) show that the adhesive joint's crack initiation may take place where the most significant stresses occur, i.e. in the corners of the adhesive joint. However, the average shear stress of the adhesive joint is at a much lower level. The value of the maximum reduced stresses at the corners of the glue line for analyzed openwork panels is shown in Fig. 12b. In the case of panels with a side wall inclination angle of $9^{\circ}$, the presented values exceed the shear strength of the adhesive used (16 MPa). 
During the tests, however, no damage was observed in the glue lines of the bent panels. This is due to the fact that the average reduced stress in the adhesive joint for all analyzed openwork panel structures did not exceed $3 \mathrm{MPa}$, thus it was significantly lower than the strength of the adhesive joint. At the same time, the values of shear stresses in the adhesive joints were significantly lower, as shown in Fig. 13.

The numerical calculations confirmed by experimental tests show that apart from sufficient stiffness, the openwork panels are characterized with very high strength of both wooden slats and glue lines. This means that the tested structures can be safe and durable.

\subsection{Energy absorption characteristic}

Energy absorption is an important indicator for assessing the amortization effectiveness of the engineering structure under study. Comparing the energy absorption capacity of the openwork structure with the solid panels allows choosing the best solution. Figure 14a, b shows the dependence of the absorbed energy on a deflection for openwork and solid panels, while Fig. $14 \mathrm{c}$ compares the values of the maximum energy absorbed by individual panels. This figure shows that the energy absorption curves are progressive, and the amount of energy absorbed disproportionately rises with increasing deflection of the panels. During bending, most of the energy is absorbed by solid panels made of ash wood $(69.2 \mathrm{~J})$. The remaining solid panels made of beech, walnut, and oak wood absorb energy in the amount of $61.6 \mathrm{~J}, 61.4 \mathrm{~J}$, and $51.1 \mathrm{~J}$, respectively. In the case of openwork panels

a)

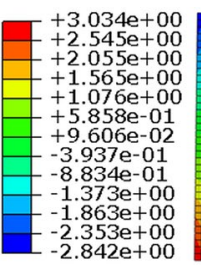

b)

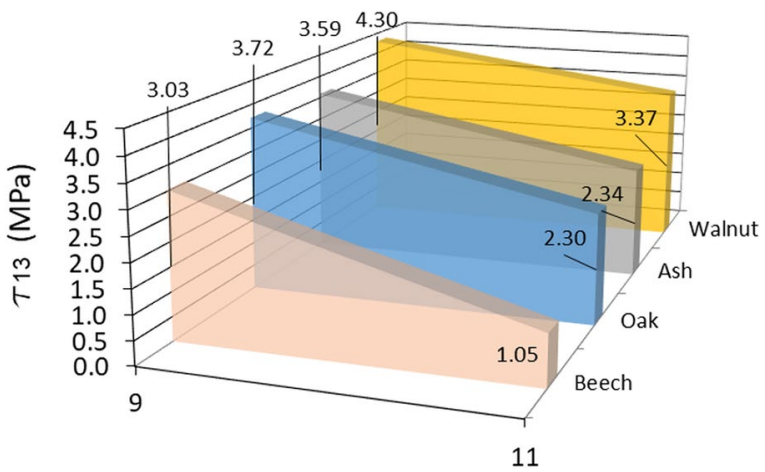

Fig. 13 Shear stresses in the glue line: stress distribution in glue line of openwork panel with inclination angle $9^{\circ}(\mathbf{a})$, the effect of wood species and inclination angle on the shear stresses in the glue line (b)
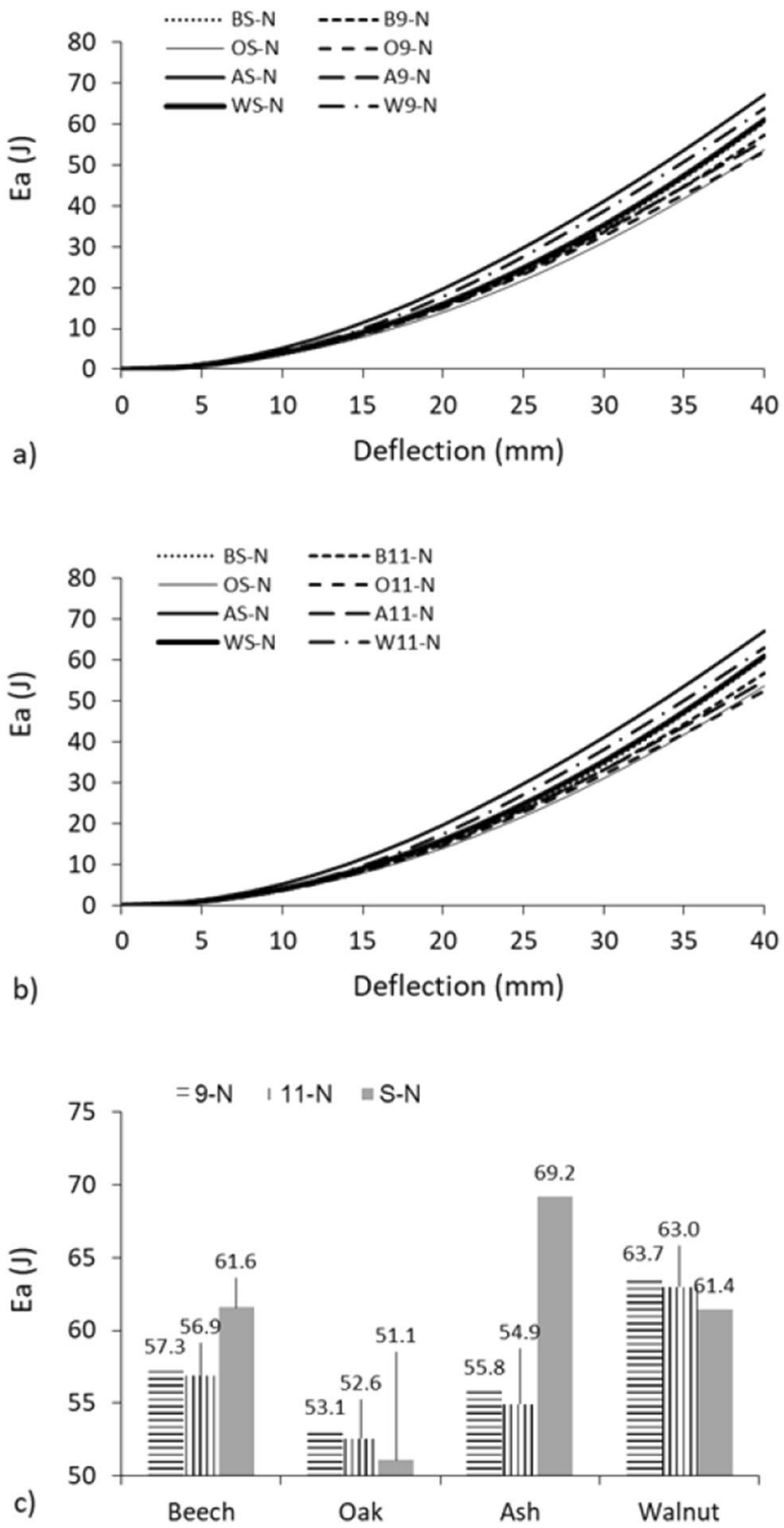

Fig. 14 Relationship between energy absorption $E_{a}(\mathrm{~J})$ and deflection $(\mathrm{mm})(\mathbf{a}, \mathbf{b})$. Maximum $E_{a}(\mathrm{~J})$ for solid and openwork panels (c), where B11, O11, A11, W11 openwork beech, oak, ash, walnut panels with inclination angle $11^{\circ}, \mathrm{B} 9,09, \mathrm{~A} 9$, W9 openwork beech, oak, ash, walnut panels with inclination angle $9^{\circ}$, respectively, $S$ solid panels

with a $9^{\circ}$ inclination angle of the side walls, the amount of energy absorbed depends on the type of wood. Compared to solid panels, openwork panels made of ash and beech absorb respectively 19.3 and $7.0 \%$ less energy, while openwork panels of walnut and oak consume 2.5 and $2.9 \%$ more energy, respectively. The increase in the inclination angle of the side walls of the curved slats from $9^{\circ}$ to $11^{\circ}$ results in a slight reduction in the amount of absorbed energy. Compared to solid panels, openwork panels of ash and beech 
$\left(11^{\circ}\right)$ absorb 20.6 and $7.6 \%$ less energy, respectively, while openwork panels of walnut and oak consume respectively 3.7 and $3.9 \%$ more energy.

The change of specific energy absorption depending on the deflection of solid and openwork wooden panels is shown in Fig. 15a, b. Figure 15c shows the maximum values of the specific absorption energy. These figures show that walnut wood panels absorb the most energy per unit of mass. Openwork panels with $9^{\circ}$ and $11^{\circ}$ inclination angles of the side walls absorb respectively 24.4 and $23.7 \mathrm{~J} / \mathrm{kg}$,

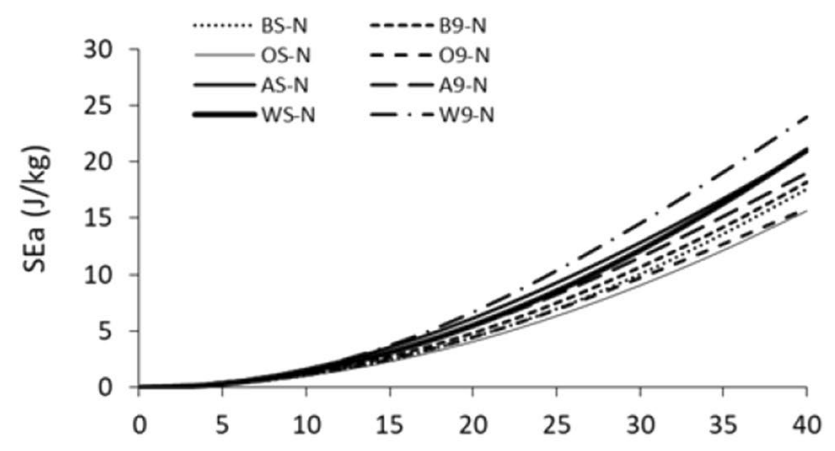

a)
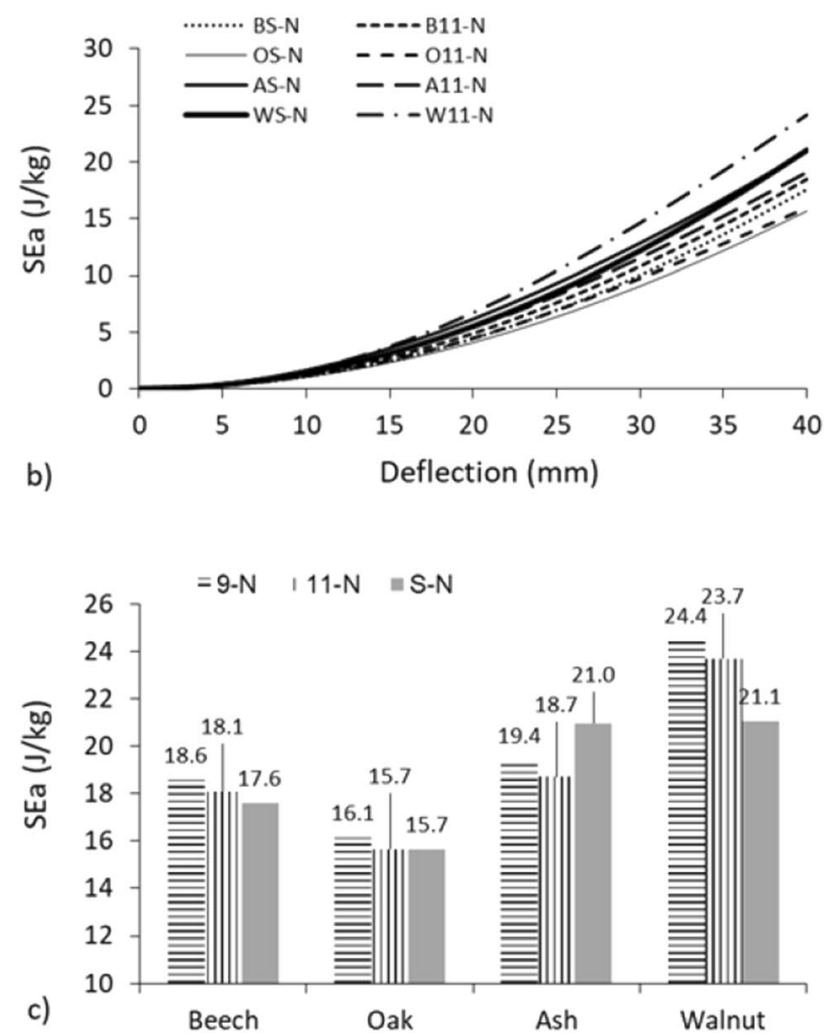

Fig. 15 Relationship between specific energy absorption $S E_{a}(\mathrm{~J} / \mathrm{kg})$ and deflection $(\mathrm{mm})(\mathbf{a}, \mathbf{b})$. Maximum $S E_{a}(\mathrm{~J} / \mathrm{kg})$ for solid and openwork panels (c) where B11, O11, A11, W11 openwork beech, oak, ash, walnut panels with inclination angle $11^{\circ}, \mathrm{B} 9, \mathrm{O} 9, \mathrm{~A} 9$, W9 openwork beech, oak, ash, walnut panels with inclination angle $9^{\circ}$, respectively, $S$ solid panels while solid panels absorb $21.1 \mathrm{~J} / \mathrm{kg}$. Openwork panels of ash with side walls inclination angles of $9^{\circ}$ and $11^{\circ}$ absorb respectively 19.4 and $18.7 \mathrm{~J} / \mathrm{kg}$, and solid panels-21.0 J/ $\mathrm{kg}$. Thus, an increase in the specific energy absorption was observed for solid ash wood panels. This is directly related to the large amount of energy absorbed by these panels during bending (Fig. 14). For panels of beech and oak, these trends are similar to those made of walnut. Openwork panels with side walls inclination angles of $9^{\circ}$ and $11^{\circ}$ absorb $18.6 \mathrm{~J} / \mathrm{kg}, 16.1 \mathrm{~J} / \mathrm{kg}, 18.1 \mathrm{~J} / \mathrm{kg}$, and $15.7 \mathrm{~J} / \mathrm{kg}$, respectively, while solid panels absorb 17.6 and $15.7 \mathrm{~J} / \mathrm{kg}$, respectively.

The presented analysis shows that the most favorable are openwork structures made of walnut wood, followed by beech and oak wood.

Figure 16 shows a histogram of the maximum bending force of the panels per unit of deflection. According to the histogram (Fig. 14) for a constant deflection value ( $40 \mathrm{~mm}$ ), the maximum bending force of $1.68 \mathrm{kN}$ is for a solid ash panel. The lowest bending forces of 1.33 and $1.31 \mathrm{kN}$ fall on oak openwork panels made of curvilinear slats with the inclination angle of the side walls of $9^{\circ}$ and $11^{\circ}$, respectively.

\section{Conclusion}

Based on the analysis of the direct results of experimental research and numerical calculations, the research hypothesis was verified, proving that openwork panels of solid wood show high stiffness and strength, similar to solid wood panels. Thus, the influence of the type of wood and the inclination angle of internal walls on the stiffness, strength, and ability to absorb energy were determined for a new type of openwork panel made of curvilinear wooden slats. It has been shown that the stiffness of openwork panels with a side wall inclination angle of $9^{\circ}$ and $11^{\circ}$ is lower by $8.5-18.3 \%$ compared to solid panels. In the case of openwork panels

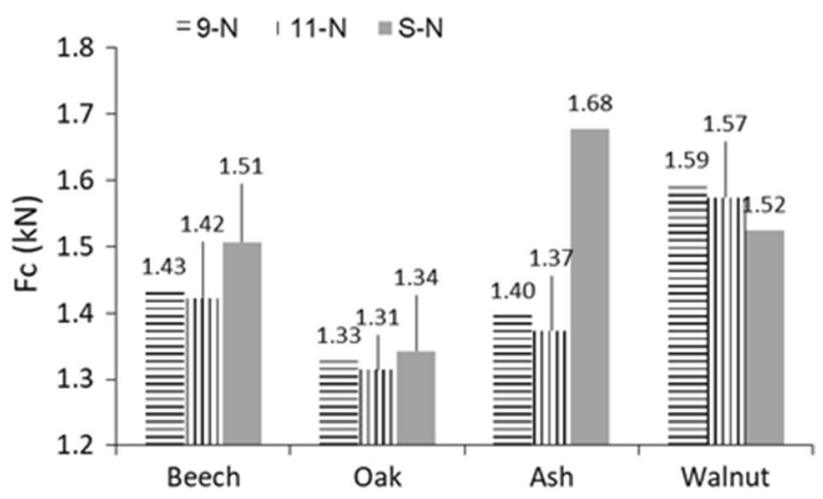

Fig. 16 Maximum crushing force for solid and openwork panels, where B11, O11, A11, W11 expanded beech, oak, ash, walnut panels with inclination angle $11^{\circ}$, B9, O9, A9, W9 beech, oak, ash, walnut panels with inclination angle $9^{\circ}$, respectively, $S$ solid panels 
with a $9^{\circ}$ side wall inclination angle, the stiffness was lower by $7.7-17 \%$. Beech wood panels showed the highest stiffness, and oak wood panels the lowest. Each of the openwork panels is also characterized by high bending strength. For a deflection of $40 \mathrm{~mm}$, the safety factors for curvilinear, wooden elements of openwork panels ranged from 1.89 to 2.09, and for solid panels from 1.72 to 1.83 . For a given deflection, no cracks in the glue lines were observed due to the low average values of the shear and reduced stresses. Compared to solid panels, the ability of openwork panels to absorb energy is very favorable. The best properties in this respect were exhibited by walnut wood for both side wall inclination angle values ( 24.4 and $23.7 \mathrm{~J} / \mathrm{kg}$ ). Considering the above, recommendations can be given to preferably produce openwork panels out of walnut and beech wood, rather than of ash and oak. It is also more advantageous for the openwork structure to use the $11^{\circ}$ inclination angle of the side walls, allowing for maximum expansion of the panel width relative to the solid panel. The conducted study also proved the correctness of the performed numerical calculations and the compliance of these calculations with experimental tests.

Acknowledgements Part of the computations were performed using computers of Poznan Supercomputing and Networking Center.

Open Access This article is licensed under a Creative Commons Attribution 4.0 International License, which permits use, sharing, adaptation, distribution and reproduction in any medium or format, as long as you give appropriate credit to the original author(s) and the source, provide a link to the Creative Commons licence, and indicate if changes were made. The images or other third party material in this article are included in the article's Creative Commons licence, unless indicated otherwise in a credit line to the material. If material is not included in the article's Creative Commons licence and your intended use is not permitted by statutory regulation or exceeds the permitted use, you will need to obtain permission directly from the copyright holder. To view a copy of this licence, visit http://creativecommons.org/licenses/by/4.0/.

\section{References}

Anshari B, Guan ZW, Kitamori A et al (2012) Structural behaviour of glued laminated timber beams pre-stressed by compressed wood. Constr Build Mater 29:24-32. https://doi.org/10.1016/j.conbu ildmat.2011.10.002

Banerjee S, Bhattacharyya D (2011) Optimal design of sandwich panels made of wood veneer hollow cores. Compos Sci Technol 71:425-432. https://doi.org/10.1016/j.compscitech.2010.12.011

Berger G, Barbu MC, Huber H et al (2016) Applying biomimicry in lightweight wood panel development. In: WCTE 2016-world conference timber engineering

Borri A, Corradi M, Grazini A (2005) A method for flexural reinforcement of old wood beams with CFRP materials. Compos Part B Eng 36:143-153. https://doi.org/10.1016/j.compositesb.2004.04. 013

Borri A, Corradi M, Speranzini E (2013) Reinforcement of wood with natural fibers. Compos Part B Eng 53:1-8. https://doi.org/10. 1016/j.compositesb.2013.04.039
Cai Z, Ross RJ (2010) Mechanical properties of wood-based composite materials. In: Wood handbook: wood as an engineering (ed) General technical report FPL ; GTR-190. U.S. Dept. of Agriculture, Forest Service, Forest Products Laboratory, Madison

Chen Z, Yan N, Deng J, Smith G (2011) Flexural creep behavior of sandwich panels containing Kraft paper honeycomb core and wood composite skins. Mater Sci Eng A 528:5621-5626. https:// doi.org/10.1016/j.msea.2011.03.092

De Jesus AMP, Pinto JMT, Morais JJL (2012) Analysis of solid wood beams strengthened with CFRP laminates of distinct lengths. Constr Build Mater 35:817-828. https://doi.org/10.1016/j.conbu ildmat.2012.04.124

EN 310:1993 (1993) Wood-based panels-determination of modulus of elasticity in bending and of bending strength. British Standards Institution, London

Fang H, Sun H, Liu W et al (2015) Mechanical performance of innovative GFRP-bamboo-wood sandwich beams: Experimental and modelling investigation. Compos Part B Eng 79:182-196. https://doi.org/10.1016/j.compositesb.2015.04.035

Farrokhabadi A, Ahmad Taghizadeh S, Madadi H et al (2020) Experimental and numerical analysis of novel multi-layer sandwich panels under three point bending load. Compos Struct 250:112631. https://doi.org/10.1016/j.compstruct.2020.112631

Gaff M, Babiak M (2018) Methods for determining the plastic work in bending and impact of selected factors on its value. Compos Struct 202:66-76. https://doi.org/10.1016/j.compstruct.2017. 11.036

Gaff M, Gašparík M, Borůvka V, Babiak M (2015a) Simulating stresses associated with the bending of wood using a finite element method. BioResources 10:2009-2019. https://doi.org/10.15376/ biores.10.2.2009-2019

Gaff M, Gašparík M, Borůvka V, Haviarová E (2015b) Stress simulation in layered wood-based materials under mechanical loading. Mater Des 87:1065-1071. https://doi.org/10.1016/j.matdes.2015. 08.128

Gaff M, Vokaty V, Babiak M, Bal BC (2016) Coefficient of wood bendability as a function of selected factors. Constr Build Mater 126:632-640. https://doi.org/10.1016/j.conbuildmat.2016.09.085

Gaff M, Gašparík M, Babiak M, Vokaty V (2017) Bendability characteristics of wood lamellae in plastic region. Compos Struct 163:410-422. https://doi.org/10.1016/j.compstruct.2016.12.052

Ha NS, Lu G (2020) A review of recent research on bio-inspired structures and materials for energy absorption applications. Compos Part B Eng 181:107496. https://doi.org/10.1016/j.compositesb. 2019.107496

Hao J, Wu X, Oporto G et al (2018) Deformation and failure behavior of wooden sandwich composites with Taiji honeycomb core under a three-point bending test. Materials (basel) 11:2325. https://doi. org/10.3390/ma11112325

Hayashi K, Ohmi M, Tominaga H, Fukuda K (2003) Effect of board density on bending properties and dimensional stabilities of MDFreinforced corrugated particleboard. J Wood Sci 49:398-404. https://doi.org/10.1007/s10086-002-0501-y

Imirzi HÖ, Smardzewski J, Döngel N (2015) Method for substitute modulus determination of furniture frame construction joints. Turk J Agric for 39:775-785. https://doi.org/10.3906/tar-1406-92

Jin M, Hu Y, Wang B (2015) Compressive and bending behaviours of wood-based two-dimensional lattice truss core sandwich structures. Compos Struct 124:337-344. https://doi.org/10.1016/j. compstruct.2015.01.033

Kamboj G, Gaff M, Smardzewski J et al (2020) Numerical and experimental investigation on the elastic stiffness of glued dovetail joints. Constr Build Mater. https://doi.org/10.1016/j.conbuildmat. 2020.120613

Kavermann SW, Bhattacharyya D (2019) Experimental investigation of the static behaviour of a corrugated plywood sandwich core. 
Compos Struct 207:836-844. https://doi.org/10.1016/j.comps truct.2018.09.094

Kawashita LF, Bedos A, Hallett SR (2012) Modelling mesh independent transverse cracks in laminated composites with a simplified cohesive segment method. Comput Mater Contin 32:133-158

Kollmann FFP, Cote WA (1968) Principles of wood science and technology I-solid wood. Springer, Heidelberg

Labans E, Kalnins K (2014) Experimental validation of the stiffness optimisation for plywood sandwich panels with RIB-stiffened core. Wood Res 59:793-802

Labans E, Kalnins K, Bisagni C (2017) Flexural behavior of sandwich panels with cellular wood, plywood stiffener/foam and thermoplastic composite core. J Sandw Struct Mater. https://doi.org/10. 1177/1099636217699587

Lakreb N, Bezzazi B, Pereira H (2015) Mechanical behavior of multilayered sandwich panels of wood veneer and a core of cork agglomerates. Mater Des 65:627-636. https://doi.org/10.1016/j. matdes.2014.09.059

Li J, Hunt JF, Gong S, Cai Z (2016) Simplified analytical model and balanced design approach for light-weight wood-based structural panel in bending. Compos Struct 136:16-24. https://doi.org/10. 1016/j.compstruct.2015.09.045

Loinsigh CO, Oudjene M, Shotton E et al (2012) Mechanical behaviour and 3D stress analysis of multi-layered wooden beams made with welded-through wood dowels. Compos Struct 94:313-321. https:// doi.org/10.1016/j.compstruct.2011.08.029

Manalo AC, Aravinthan T, Karunasena W (2010) Flexural behaviour of glue-laminated fibre composite sandwich beams. Compos Struct 92:2703-2711. https://doi.org/10.1016/j.compstruct.2010.03.006

Murlak K (2019) Method for producing the openwork plank and the openwork plank made from wood. Patent Office of the Republic of Poland, P.42481

Negro F, Cremonini C, Zanuttini R, Properzi M (2011) A new wood-based lightweight composite for boatbuilding. Wood Res 56:257-266

Penellum M, Sharma B, Shah DU et al (2018) Relationship of structure and stiffness in laminated bamboo composites. Constr Build Mater 165:241-246. https://doi.org/10.1016/j.conbuildmat.2017.12.166

Qi Y, Fang H, Shi H et al (2017) Bending performance of GFRP-wood sandwich beams with lattice-web reinforcement in flatwise and sidewise directions. Constr Build Mater 156:532-545. https://doi. org/10.1016/j.conbuildmat.2017.08.136

Qiu LP, Zhu EC, van de Kuilen JWG (2014) Modeling crack propagation in wood by extended finite element method. Eur J Wood Prod 72:273-283. https://doi.org/10.1007/s00107-013-0773-5

Reynolds T, Sharma B, Harries K, Ramage M (2016) Dowelled structural connections in laminated bamboo and timber. Compos Part B 90:232-240. https://doi.org/10.1016/j.compositesb.2015.11.045

Ruman D, Záborský V, Svoboda T et al (2017) Identifying the characteristics of laminated wood based on the values of deflection measured during its bending. BioResources 12(2):2592-2608. https://doi.org/10.15376/biores.12.2.2592-2608

Schneider C, Zenkert D, Deshpande VSS, Kazemahvazi S (2016) Bending energy absorption of self-reinforced poly(ethylene terephthalate) composite sandwich beams. Compos Struct 140:582589. https://doi.org/10.1016/j.compstruct.2015.12.043

Sharma B, Gatóo A, Bock M, Ramage M (2015) Engineered bamboo for structural applications. Constr Build Mater 81:66-73. https:// doi.org/10.1016/j.conbuildmat.2015.01.077

Skuratov N (2010) New lightweight solid wood panels for green building. In: Proceedings of the international convention of society of wood science and technology and United Nations Economic Commission for Europe-Timber Committee, October 11-14, 2010, Geneva, Switzerland, p 1-7

Smardzewski J (1996) Numerical analysis of furniture constructions. Wood Sci Technol 32:273-286. https://doi.org/10.1007/BF007 02895
Smardzewski J (2002) Strength of profile-adhesive joints. Wood Sci Technol 36:173-183. https://doi.org/10.1007/s00226-001-0131-3

Smardzewski J (2008) Effect of wood species and glue type on contact stresses. J Mech Eng Sci 222:1-7. https://doi.org/10.1243/09544 062JMES1084

Smardzewski J (2013) Elastic properties of cellular wood panels with hexagonal and auxetic cores. Holzforschung 67:87-92. https://doi. org/10.1515/hf-2012-0055

Smardzewski J (2015) Furniture design, 1st edn. Springer, Heidelberg

Smardzewski J (2019a) Experimental and numerical analysis of wooden sandwich panels with an auxetic core and oval cells. Mater Des 183:108159. https://doi.org/10.1016/j.matdes.2019. 108159

Smardzewski J (2019b) Wooden sandwich panels with prismatic core-energy absorbing capabilities. Compos Struct 230:111535. https://doi.org/10.1016/j.compstruct.2019.111535

Smardzewski J, Jasińska D (2016) Mathematical models and experimental data for HDF based sandwich panels with dual corrugated lightweight core. Holzforschung 71:265-273. https://doi.org/10. 1515/hf-2016-0146

Sun G, Huo X, Chen D, Li Q (2017) Experimental and numerical study on honeycomb sandwich panels under bending and in-panel compression. Mater Des 133:154-168. https://doi.org/10.1016/j. matdes.2017.07.057

Susainathan J, Eyma F, De Luycker E et al (2017) Manufacturing and quasi-static bending behavior of wood-based sandwich structures. Compos Struct 182:487-504. https://doi.org/10.1016/j.comps truct.2017.09.034

Susainathan J, Eyma F, De Luycker E et al (2018) Experimental investigation of impact behavior of wood-based sandwich structures. Compos Part A Appl Sci Manuf 109:10-19. https://doi.org/10. 1016/j.compositesa.2018.02.029

Tran VD, Oudjene M, Méausoone PJ (2015) Experimental and numerical analyses of the structural response of adhesively reconstituted beech timber beams. Compos Struct 119:206-217. https://doi.org/ 10.1016/j.compstruct.2014.08.013

Wdowiak-Postulak A, Brol J (2020) Ductility of the tensile zone in bent wooden beams strengthened with CFRP materials. Materials (basel) 13:5451. https://doi.org/10.3390/ma13235451

Yaddanapudi HS, Hickerson N, Saini S, Tiwari A (2017) Fabrication and characterization of transparent wood for next generation smart building applications. Vacuum 146:649-654. https://doi.org/10. 1016/j.vacuum.2017.01.016

Yan LL, Han B, Yu B et al (2014) Three-point bending of sandwich beams with aluminum foam-filled corrugated cores. Mater Des 60:510-519. https://doi.org/10.1016/j.matdes.2014.04.014

Yang Y, Liu J, Xiong G (2013) Flexural behavior of wood beams strengthened with HFRP. Constr Build Mater 43:118-124. https:// doi.org/10.1016/j.conbuildmat.2013.01.029

Yazdani Sarvestani H, Akbarzadeh AH, Mirbolghasemi A, Hermenean K (2018) 3D printed meta-sandwich structures: failure mechanism, energy absorption and multi-hit capability. Mater Des 160:179-193. https://doi.org/10.1016/j.matdes.2018.08.061

Zhang Q, Yang X, Li P et al (2015) Bioinspired engineering of honeycomb structure-using nature to inspire human innovation. Prog Mater Sci 74:332-400. https://doi.org/10.1016/j.pmatsci.2015. 05.001

Zhong Y, Wu G, Ren H, Jiang Z (2017) Bending properties evaluation of newly designed reinforced bamboo scrimber composite beams. Constr Build Mater 143:61-70. https://doi.org/10.1016/j.conbu ildmat.2017.03.052

Publisher's Note Springer Nature remains neutral with regard to jurisdictional claims in published maps and institutional affiliations. 